Przemysław Rotengruber

Adam Mickiewicz University in Poznan

Faculty of Social Sciences, Institute of Cultural Studies

e-mail: proten@amu.edu.pl

\title{
Słowa i czyny. O społecznej (nie)odpowiedzialności uniwersytetu
}

\section{Words and Deeds. Corporate Social (Ir)Responsibility in Higher Education Institutions}

The purpose of the paper is twofold. Firstly, to formulate a definition of a university's social responsibility that takes into account social expectations from this institution and its internal determinants. The final result of this research is a definition built on two concepts. On the one hand, it is a stakeholder policy, on the other hand, a whistleblower policy. These are the criteria of responsibility, i.e., the rules that make an institution transparent and open to social criticism. Secondly, the article poses the question whether a university in Poland (treated as a dominant institution of knowledge) is rightly seen as an irresponsible partner of civil society? From the business ethics perspective, the more responsible a university is, the more intense are its ties with the social environment represented by stakeholders and whistleblowers. When they fail to play their parts properly, the relationships should be considered dysfunctional. Additional explanation of this problem may be found in the theory of management. Using the concept of the final customer, public opinion can discover if it really is the main interlocutor of the university. The social partners of the university focus their attention on politicians and public administration as the alternative final customer of the academic product.

Keywords: university, social responsibility, stakeholder, whistleblower, final customer

JEL Classification: I23, I28, M14 


\section{Co to jest odpowiedzialność instytucjonalna? Wprowadzenie}

Odpowiedzialność należy do pojęć, w których kumulują się trudności reprezentatywne dla nauk humanistycznych i społecznych. W procesie socjalizacji odgrywa ono rolę zwornika łączącego jakościowo różne oczekiwania odnośnie do wyniku pracy wychowawczej. W tym rozumieniu odpowiedzialność uchodzić może za synonim integralności osoby kształtującej swój stosunek do siebie i innych. Kształtowanie to $\mathrm{z}$ pozoru tylko sprowadza się do przyswojenia reguł zachowania obowiązujących w jej społecznym otoczeniu. Reguły te bowiem cechuje różnorodność. W jednym przypadku od jednostki przystosowanej oczekuje się, by była lojalna, w drugim, by umiała upomnieć się o swoje, w trzecim wreszcie, by postępowała rozważnie. Gwoli ścisłości, ostatnie kryterium należałoby wziąć w cudzysłów. Rozwaga Jezusa rozmawiającego z Szatanem nie jest równa rozwadze Odyseusza oślepiającego Polifema. Tymczasem obie opowieści należą do kanonu wzorców kultury zachodniej. Dlatego rozwagi, podobnie jak odpowiedzialności, nie sposób oceniać inaczej niż przez osadzenie postulatu integralności w przestrzeni subiectum. To podmiot dokonuje wyboru wzorców, z którymi chce się identyfikować. Łączy przy tym wymóg konsekwencji w posługiwaniu się nimi ze świadomością celów, które - za ich pomocą - chce osiągnąć.

$\mathrm{Z}$ rzeczonej obserwacji wynika, że odpowiedzialność jest pojęciem wieloznacznym. Próżno szukać w nim rozwiązania problemów dzielących społecznych interlokutorów. Etymologicznie rzecz biorąc, są oni zobowiązani do przedstawiania sobie nawzajem motywów swego postępowania. Na tym jednak sprawa się kończy. Informując się o tym, co czynią i uzasadniając swój wybór preferowanym systemem wartości (wzorców kultury) unikają oni zarzutu decyzyjnej niespójności czy nieprzewidywalności w działaniu ${ }^{1}$. Sytuacja zmienia się diametralnie, kiedy jednym z celów, o który zabiega odpowiedzialny podmiot jest budowanie - wraz z innymi - więzi opartych na zaufaniu. Tak rozpoczyna się dialog ${ }^{2}$. Rozpoczyna się, potencjalnie, od pierwszych chwil życia każdego z nas. Wszak trudno zakładać, że człowiek zdrowy na ciele i duchu nie odczuwa potrzeby bliskości, partnerstwa, czy choćby zrozumienia. To rodzi wzajemność uzasadnioną potrzebą ochrony czegoś, co uznane zostało za pozytywną wartość. Niestety, w powszednich realiach uzasadnienie to częstokroć zawodzi. Doświadczenie niepowiązane z korzyścią własną okazuje się niewystarczalne. Sięgając po wyjaśnienie Abrahama Maslowa, przed

\footnotetext{
${ }^{1}$ Pomijam obowiązek przestrzegania prawa. Państwo ustanawia odpowiedzialność obligatoryjną za naruszenie jego zasad. Myli się jednak ten, kto sądzi, że są one kwintesencją społecznej odpowiedzialności obywatela. Jest raczej tak, że jest on rozdarty pomiędzy porządkiem stanowionym przez prawodawcę a ładem, który - w większym rozciągnięciu czasowym - ukształtował się spontanicznie.

${ }^{2}$ P. Rotengruber, Ideologia, anarchia, etyka. Dyskurs ponowoczesny a dialog, Wyd. Nauk. HUMANIORA, Poznań 2000.
} 
potrzebą szacunku i samorealizacji umieszczamy (zwykle) sprawy związane z bezpieczeństwem i dostatkiem ${ }^{3}$. Również te cele stanowią przecież komponent odpowiedzialności, nawet jeśli odpowiedzialności li tylko za siebie ${ }^{4}$.

Dokonane ustalenia znajdują przełożenie na kwestię odpowiedzialności organizacyjnej. Instytucje albo (wprost) powołane do tego, by służyć innym, albo czerpiące rację istnienia z aprobaty innych, nie mogą unikać pytania o związki łączące je z ich społecznym otoczeniem. Z pozoru prostsze wydaje się położenie organizacji gospodarczych. W ich przypadku o powodzeniu ich misji decyduje kryterium rynkowe. Kierując się tym wskazaniem, przewagę konkurencyjną powinno osiągać przedsiębiorstwo dostarczające pełniejszej (i pewniejszej) informacji o swoim produkcie. Wskazana zależność nie dostarcza jednak pełnego obrazu relacji zachodzących na rynku. W jego obszarze nie tylko lepsze wypiera gorsze, lecz także tańsze wypiera droższe. Zdarza się więc, że mniej wiarygodny oferent „nadrabia ceną” straty wizerunkowe wywołane zaniechaniami informacyjnymi bądź jakościowymi. Kiedy jednak zależność tę poddać czasowemu rozciągnięciu, nadrabianie owych strat okazuje się arcytrudne. Abraham Maslow thumaczy to przenoszeniem akcentu przez uczestników życia gospodarczego z ich celów merkantylnych na zobowiązania społeczne, Ronald Inglehart - postmaterialistycznym nastawieniem społeczeństw zachodnich, Ulrich Beck - wszechobecnym ryzykiem, któremu owe społeczeństwa - z coraz większym trudem - usiłują stawić czoła ${ }^{5}$. Przynajmniej w tej optyce odpowiedzialne gospodarowanie uznane być może za postępowanie (potencjalnie) opłacalne.

Mniej optymistycznie przedstawia się obraz instytucji świadczących usługi publiczne. Petent, uczeń, a nawet pacjent (zwłaszcza ten z książeczką zdrowia), z pozoru tylko są ich odbiorcami finalnymi. Owszem, nie wolno lekceważyć wymienionych aktorów. Kumulacja ich złych nastrojów może zwrócić się przeciwko niesolidnemu usługodawcy. Tego rodzaju ewentualność na ogół jawi się jako na tyle odległa, że nie zaprząta zbytnio uwagi usługodawcy. W praktyce powszedniej skupia się on przede wszystkim na podmiotach finansujących jego działalność. Rzec by można, że uaktywnia się tu mechanizm rynkowy. Tyle, że uaktywnia się w specyficzny sposób. Ważniejszy od tych, którzy (płacąc podatki) dostarczyli środków na funkcjonowanie instytucji publicznych jest polityczny pośrednik. To on decyduje jak owe środki podzielić. Dominującym medium sterowania staje się władza administracyjna ${ }^{6}$. Pociąga to za sobą trudne do oszacowania skutki. Niewiadomą główną jest mianowicie to, czy placówki zależne od tejże władzy zadowolą się rolą (ślepego) wykonawcy jej postanowień, czy ich ambicją będzie dochowanie wierności zawodowym ideałom kształtowanym w związku z pełnieniem przez nie misji publicznej.

${ }^{3}$ Cf. A.H. Maslow, Motywacja i osobowość, przeł. P. Sawicka, PAX, Warszawa 1990, s. 72-92.

${ }^{4}$ D. Hume, Badania dotyczace zasad moralności, przeł. M. Filipczuk, T. Tesznar, Wyd. Zielona Sowa, Kraków 2005, s. 5. Cf. A.J. Ayer, Language, Truth and Logic, Penguin, London 2001, s. 158-161.

${ }^{5}$ A.H. Maslow, op. cit.; R. Inglehart, Culture Shift in Advanced Industrial Societies, Princeton University Press 1990; U. Beck, Spoleczeństwo ryzyka. W drodze do innej nowoczesności, przeł. S. Cieśla, Wyd. Nauk. SCHOLAR, Warszawa 2002.

${ }^{6}$ J. Habermas, Faktyczność i obowiqzywanie, przeł. A. Romaniuk, R. Marszałek, PWN, Warszawa 2005, s. $50-51,53$. 
Szczególnie złożony wydaje się przypadek uniwersytetu ${ }^{7}$. Jako instytucja wiedzy akumulująca najcenniejsze zasoby kulturowe a zarazem monopolizująca uprawnienia do certyfikowania - najpotrzebniejszej społecznie - wiedzy i umiejętności, posiada ona autorytet możliwy do wykorzystania w politycznej grze o niezależność. Nie chodzi przy tym o prawo weta jako cel sam w sobie. Celem tym jest raczej zachowanie wiarygodności. Autorytet uniwersytetu znika, kiedy poddaje się on politycznej presji. Politycy bowiem nie wiedzą lepiej od środowiska akademickiego ani tego, czym jest nauka, ani jakie są jej społeczne zastosowania. Mają natomiast środki po temu, by urzeczywistniać swoje plany. To stawia uniwersytet w trudnej sytuacji. $Z$ jednej strony ma on służyć prawdzie. $Z$ drugiej strony, jego emancypacyjne zapędy prowadzić mogą do konfliktu z tymi, którzy łożą na jego utrzymanie. Sam uniwersytet nie jest zresztą bez winy. Tyleż w nim braków i decyzyjnych uchybień, ile dookoła niego. Symbolem tego niech będzie zacierająca się dystynkcja odróżniająca (do niedawna) ludzi wykształconych od niewykształconych. Polityka państwa - wynikiem której jest absurdalnie wysoki współczynnik scholaryzacji - krzyżuje się tu z zaangażowaniem polskich szkół wyższych w proces „masowej produkcji” absolwentów. Kogo przyjmują na studia, jakimi zasobami dysponują (kadra, infrastruktura itd.), stosowanie jakich standardów kształcenia są one w stanie zagwarantować? Te zagadnienia tym mniej absorbują uwagę władz rektorskich, im więcej trudności przysparza im pozyskanie „zadowalającej” liczby studentów.

Uniwersytet ma wszelkie powody po temu, by krytykę rozwiązań systemowych połączyć z rachunkiem sumienia. Chodzi wszak o coś więcej niż o jego autonomię. Celem nie mniej ważnym jest ochrona wizerunku mediatora i przewodnika. Społeczne funkcje uniwersytetu, inaczej niż jego uprawnienia, ulegają zanikowi wraz z utratą wiary w jego społeczną odpowiedzialność. Podkreślenia wymaga, iż w tym oświetleniu pojęcie odpowiedzialności nie jest obciążone dwuznacznością. Społeczni partnerzy uniwersytetu pytają o ustalenia dotyczące tego, jak być powinno będące integralnym elementem jego oferty edukacyjnej. Pytają nie tylko o wartość wiedzy gromadzonej przez uniwersytet, lecz także o sposób posługiwania się nią. Poruszając drugą kwestię do niedawna skupiali się oni na skutkach nieetycznego wykorzystania odkryć naukowych ${ }^{8}$. Dziś dużo bardziej niepokoi ich alienacja tej instytucji przejawiająca się jej wymykaniem się spod społecznej kontroli. Podążając tym tropem, przedmiotem artykułu czynię związki zachodzące pomiędzy koncepcją społecznej odpowiedzialności biznesu (Corporate Social Responsibility, CSR) a stosunkiem uniwersytetu do jego społecznego otoczenia. Zamierzam wykazać, że choć uniwersytet nie jest przedsiębiorstwem, to po uwzględnieniu różnic dzielących obie instytucje, przywołana koncepcja znajduje zastosowanie w badaniach nad moralną i polityczną kondycją szkół wyższych w Polsce?

\footnotetext{
${ }^{7} \mathrm{Na}$ potrzeby niniejszych analiz traktuję uniwersytet jako synonim uczelni wyższej (w całości bądź w części) finansowanej ze środków publicznych.

${ }^{8}$ Cf. I. Lakatos, Społeczna odpowiedzialność nauki [w:] Pisma z filozofii nauk empirycznych, przeł. W. Sady, WN PWN, Warszawa 1995, s. 363-366.

${ }^{9}$ Cf. M. Geryk, Społeczna odpowiedzialność uczelni, Oficyna wydawnicza SGH, Warszawa 2012.
} 


\section{Społeczna odpowiedzialność biznesu: doktryna, trudności definicyjne, zastosowania}

Doktryna społecznej odpowiedzialności biznesu ma ponad sto lat. W opublikowanej w 1889 roku The Gospel of Wealth amerykański magnat stalowy Andrew Carnegie skojarzył społecznie odpowiedzialne gospodarowanie z szacunkiem przedsiębiorcy dla zasad powierniczości i dobroczynności (stewardship, charity) ${ }^{10}$. Zasady te, poza względami moralnymi, podpowiadał zdrowy rozsądek. Carnegie przekonany był, że o sile przedsiębiorcy decyduje trwałość jego związków z tymi, którzy powierzyli mu swój los, oraz opinia tych, którzy współtworzą jego społeczne otoczenie. Minął tymczasem wiek, wraz z którym w niepamięć odeszły fabryki z czerwonej cegły z nazwiskiem właściciela umieszczonym nad bramą. Dziś jego miejsce zajęli akcjonariusze i menedżerowie ${ }^{11}$. W diametralnie zmienionych okolicznościach powraca pytanie o tożsamość aktorów połączonych relacją (społecznej) odpowiedzialności. Na szczególną uwagę zasługuje fakt, iż postulat dobroczynności przedsiębiorstwa nie komponuje się spontanicznie $\mathrm{z}$ jego zobowiązaniami powierniczymi. Przeszkodą główną jest rachunek ekonomiczny. Inwestycje w wizerunek firmy społecznie odpowiedzialnej niepoparte szacunkami odnośnie do spodziewanych korzyści, narażają biznesowego filantropa na zarzut niegospodarności ${ }^{12}$.

Wymienione trudności nie powodują spadku zainteresowania doktryną społecznej odpowiedzialności biznesu. Przeciwnie, stała się ona jednym z głównych instrumentów polityki publicznej państw zachodnich. Jej polityczny użytkownik nie poprzestał przy tym na kontrolowaniu za jej pomocą przedsiębiorstw, czy szerzej, organizacji komercyjnych. Znalazł dla niej inne - pozagospodarcze bądź okołogospodarcze - zastosowania. Niestety owo rozszerzenie wzmocniło zamiast osłabić wcześniej wyrażone obawy. Do problemu jednostronności spornego postulatu oraz ekonomicznego uzasadnienia przez firmę kosztów jego wdrożenia dołączyła niejasność dotycząca granic społecznej odpowiedzialności instytucji publicznych. Menedżerowie zastanawiają się, czy wolno im rozdawać pieniądze powierników, urzędnicy zaś - dlaczego ich praca miałaby podlegać kontroli innej niż ta, sprawowana przez ich przełożonych oraz organy nadzoru zewnętrznego. Wobec wskazanego we wprowadzeniu zamierzenia badawczego, rozwinięcia wymagają obie wątpliwości.

W pierwszym przypadku rozpocząć należy od wyjaśnienia, czemu służyć ma dobroczynność w społecznie odpowiedzialnym zarządzaniu organizacją nastawioną na osiąganie zysków. Czy chodzi tu o zachowanie pozorów bezinteresowności na potrzeby polityków i opinii publicznej? Zdecydowanie nie. Jakkolwiek błędem byłoby lekceważenie rzeczonych zastosowań, nie są one głównym atutem strategii

\footnotetext{
${ }^{10}$ J. Sójka, L.V. Ryan, Etyka biznesu, Wyd. „W drodze”, Poznań 1997, s. 5-11.

${ }^{11}$ J. Sójka, Wstęp [w:] Etyka biznesu 'po Enronie', red. J. Sójka, Wyd. Fundacji Humaniora, Poznań 2005 , s. 12.

${ }^{12}$ A. Lewicka-Strzałecka, Odpowiedzialność moralna $w \dot{z y c i u}$ gospodarczym, IFiS PAN, Warszawa 2006, s. 22-26.
} 
CSR-owej. Pomijając rolę, jaką w czasach Carnegiego odgrywała dobroczynność (jako przepis na budowanie osobistego prestiżu), w jego doktrynie została ona skojarzona z zasadą powierniczości. Połączenie to decyduje o prawidłowym odczytaniu jego przesłania. Miejsce rozdawnictwa zajmuje mianowicie pozyskiwanie zaufania społecznego otoczenia przedsiębiorstwa. Inwestując w takie przymioty (cechy wizerunkowe) jak solidność, przewidywalność czy przyzwoitość, osiąga ono przewagę konkurencyjną nad rywalami ${ }^{13}$. W aspekcie informacyjnym i jakościowym podejmuje decyzje, których opłacalność daje się obliczyć.

Paralelnym zagadnieniem jest szacowanie strat będących następstwem CSRowych zaniechań. Zwłaszcza wtedy, gdy działalność gospodarcza ma charakter ciągły, nawarstwiające się obiekcje wokół jej organizatora narażają go na społeczny ostracyzm. To pociąga za sobą koszty wynikające $\mathrm{z}$ odmowy uczestnictwa w rynkowej grze z jej niepewnym uczestnikiem. Właśnie tu znajduje zastosowanie doktryna społecznej odpowiedzialności biznesu. W ujęciu sumującym dokonania etyków gospodarczych i teoretyków zarządzania jest ona kompilacją programów badawczych dedykowanych interesariuszom i demaskatorom. Ich wybór nie jest przypadkowy. Wymienione strategie dostarczają kryteriów odpowiedzialności zarządczej przedsiębiorstwa zgodnych z oczekiwaniami jego społecznego otoczenia. Kryteria te mają podwójne zastosowanie. Z jednej strony, podmiot gospodarczy nie może obyć się bez wiedzy o zagrożeniach, źródłem których są jego społeczni partnerzy. Z drugiej strony, owych partnerów warto włączać w proces zarządczy poprzez uzgadnianie $\mathrm{z}$ nimi tego, co składa się na interes partykularny każdego $\mathrm{z}$ nich z osobna, oraz tego, co leży w interesie publicznym.

Zarządzanie organizacją stawało się będzie odpowiedzialne dopiero wtedy, gdy towarzyszyły temu będą decyzje społecznie i gospodarczo policzalne. To odsyła do dwóch pytań: (1) jak - z perspektywy zarządczej - oceniać kwalifikacje menedżera skonfrontowanego z wyzwaniami społecznymi; oraz (2) jak - z perspektywy ulicy - rozeznawać się w intencjach gospodarczego interlokutora deklarującego społeczną odpowiedzialność? We współczesnych realiach biznesowych (nazywanych niekiedy kapitalizmem menedżerskim ${ }^{14}$ ) posługiwanie się doktryną CSR z pominięciem wymienionych kryteriów nie może służyć niczemu poza wprowadzaniem w błąd sobie i innych. Teza ta, jakkolwiek radykalna, znajduje uzasadnienie. Zawiera się ono $\mathrm{w}$ alternatywie, zgodnie $\mathrm{z}$ którą albo celem przedsiębiorstwa jest gromadzenie wiedzy o jego społecznych partnerach i pozyskiwanie ich zaufania, albo ich (permanentne) dezinformowanie ujawniające wrogie zamiary podmiotu nominalnie odpowiedzialnego. Opowiadając się za pierwszym wariantem ustalić trzeba jak stosować się do CSR-owych wymogów.

Podniesienia wymaga, iż orientowanie się w nastawieniu społecznego otoczenia jest obowiązkiem menedżera poprzedzającym wybór strategii społecznie odpowiedzialnego gospodarowania. Niezależnie od oceny etycznej przedsiębiorstwa wymóg czujności jego włodarzy obejmującej społeczne wyzwania jest warunkiem

\footnotetext{
${ }^{13}$ P. Rotengruber, Moralność krańcowa jako przedmiot badania oraz jako wiedza o sposobach osiagania przewagi konkurencyjnej, „Annales. Etyka w Życiu Gospodarczym” 2013, vol. 16, s. 45-54.

${ }^{14}$ W.M. Evan, R.E. Freeman, Spótka i osoby żywotnie zainteresowane. Kapitalizm kantowski, przeł. E. Dratwa [w:] Etyka biznesu, red. L.V. Ryan, J. Sójka, op. cit., s. 185-205.
} 
koniecznym ich zawodowej przydatności (kryterium sprawnościowe). Doprecyzowując myśl, menedżer nieorientujący się w społecznych skutkach działań podjętych przez jego firmę naraża ją na straty (przynajmniej wizerunkowe). Potwierdza w ten sposób, że jest złym zarządcą. Tym bardziej trudno brać poważnie jego deklaracje dotyczące społecznej odpowiedzialności, kiedy nie wie przed kim oraz za co ma odpowiadać. Wraz z tym twierdzeniem akcent przeniesiony zostaje z pytania, czy rozwijać zarządczą umiejętność orientowania się w społecznych realiach, na to, jak ją rozwijać.

Rozwiązaniem - nawet jeśli rozwiązaniem niedoskonałym - jest koncepcja interesariuszy. Zdaniem R. Edwarda Freemana interesariuszem jest każdy, kto uważa, że poniósł stratę z powodu nadużyć lub błędów zarządczych popełnionych przez przedsiębiorstwo $^{15}$. Poza pracownikami, klientami bądź kooperantami, do grupy tej należą aktorzy powiązani z nim zależnościami pośrednimi, tacy jak społeczność lokalna czy jego konkurenci. Miarą zapobiegliwości menedżera jest znajomość interesariuszy połączona $\mathrm{z}$ umiejętnością prognozowania zagrożeń dla przedsiębiorstwa, których mogą oni być sprawcami. Niestety, tak zdefiniowanym ryzykiem nie sposób zarządzać. Zagrożenie jest bowiem wszechobecne. Zapewne to skłoniło Freemana do zmiany poglądów na trwałość (i powszechność) uprawnień przysługujących interesariuszom ${ }^{16}$. Wspólnie $z$ Williamem M. Evanem uprawnienia te skojarzyli z etyką kantowską, nakładającą na przedsiębiorstwo (imperatywny) wymóg ochrony podmiotowości - każdego bez wyjątku - uczestnika życia gospodarczego ${ }^{17}$. Tymczasem argumentacja transcendentalna okazała się zawodna. Interesariuszy, zgodnie z przestrogą Ronalda K. Mitchella, należy traktować poważnie nie tylko dlatego, że bywają natarczywi i silni, lecz również ze względu na rolę, jaką w sytuacjach konfliktowych odgrywają ich przekonania moralne ${ }^{18}$. Przedmiotem kolejnej korekty Freemana stały się więc różnice w pojmowaniu reguł sprawiedliwości dzielące gospodarczych interlokutorów ${ }^{19}$. Nawet wtedy, gdy postępują uczciwie, nie można mieć pewności, czy formułując roszczenie, posługują się oni tą samą miarą, co jego adresat. Konsekwencją tego stanu rzeczy jest obowiązek łączenia przez menedżera odpowiedzialności wobec interesariuszy z troską o dobro firmy. Musi on rozumieć tych, którzy mają do niej zastrzeżenia, a zarazem wiedzieć, co jest przedmiotem jego (szczególnej) ochrony.

\footnotetext{
${ }^{15}$ R.E. Freeman, Strategic Management: A Stakeholder Approach, Pitman Publishing, Boston 1984; R.E. Freeman, J. McVea, A Stakeholder Approach to Strategic Management, „Social Science Research Network Electronic Paper Collection" 2001, s. 48, doi: 10.2139/ssrn.263511; S. Young, Etyczny kapitalizm. Jak na powrót połaczyć prywatny interes z dobrem publicznym, przeł. W. Kisiel, METAmorfoza, Wrocław 2005, s. VIII.

${ }^{16}$ C. Wicks, R.E. Freeman, Organization Studies and the New Pragmatism: Positivism, Anti-positivism, and the Search for Ethics, „Organization Science” 1998, vol. 9, nr 2, s. 123-140.

${ }^{17}$ W.M. Evan, R.E. Freeman, op. cit., s. 186-187.

${ }^{18}$ R.K. Mitchell, B.R. Agle, D.J. Wood, Toward a Theory of Stakeholder. Identification and Salience: Defining the Principle of Who and What Really Counts, „Academy of Management Review” 1997, vol. 22, nr 4, s. 853-886. Cf. T. Mendel, Partycypacja w zarzązaniu wspótczesnymi organizacjami, Wyd. Akademii Ekonomicznej w Poznaniu, Poznań 2001, s. 16-18.

${ }^{19}$ R. Phillips, R.E. Freeman, A.C. Wicks, What Stakeholder Theory Is Not „Business Ethics Quarterly” 2005, vol. 13, nr 4, s. 479-502.
} 
Podobnie ma się sprawa z postulatem pozyskiwania zaufania za pomocą mechanizmu demaskacji. Potwierdzona stosownymi gwarancjami gotowość poddania się przez przedsiębiorstwo społecznej kontroli napotyka przeszkodę w postaci uznania nadrzędności interesu publicznego nad zasadą poufności (wiążącą pracowników, kooperantów, ekspertów itd.). Ujmując rzecz zwięźle, etycy gospodarczy i teoretycy zarządzania charakteryzują demaskację jako akt nielojalności uzasadniony intencją obrony dobra wspólnego. Są oni zgodni co do tego, że demaskator jest osobą, która ujawnia tajemnice firmy z pobudek etycznych narażając się przez to na karę za „wścibstwo” bądź „donosicielstwo”. Zarazem badaczy zajmujących się owym zagadnieniem dzieli to, czy na uwagę opinii publicznej w równym stopniu zasługują demaskatorzy będący (obecnymi bądź dawnymi) członkami piętnowanej organizacji, co ci lokujący się poza nią, względnie sytuujący się na jej obrzeżach. Kością niezgody jest miarodajny dostęp demaskatorów poza-organizacyjnych do informacji niejawnych, ich niejasne intencje oraz (rzekomo) niższe ryzyko odwetu będącego następstwem aktu demaskacji ${ }^{20}$.

Spór o definicję demaskatora ma znaczenie, gdyż jego następstwem jest - dokonująca się w świadomości zbiorowej - selekcja wzorców postępowania stosowanych $\mathrm{w}$ walce $\mathrm{z}$ podmiotami zagrażającymi porządkowi publicznemu. Trudno odmówić racji tym, którzy nie chcą stawiać znaku równości pomiędzy najrozmaitszymi przejawami pieniactwa, podrażnionej ambicji czy oportunizmu, a działaniem podejmowanym $\mathrm{w}$ interesie społecznym ${ }^{21}$. Wraz $\mathrm{z}$ tym jednak nie wolno tracić z pola widzenia niebezpieczeństwa polegającego na dyskredytowaniu wszystkich bez wyjątku aktorów wcielających się w rolę demaskatora. Owszem, jest tu miejsce na wątpliwości. Rzecz w tym, by nie przesłaniały one etycznej strony przedsięwzięcia. Łatwą do przewidzenia reakcją organizacji, której ciemne sprawy ujrzały światło dzienne, jest kwestionowanie wiarygodności informatora. Nazbyt szybkie opowiadanie się przeciwko niemu, czy choćby obojętność wobec niego, skutkują tym, że dziecko zostaje ,wylane z kąpielą”. Mając to na względzie stwierdzić należy, iż miarą zdrowia uczestników życia publicznego jest sprawność mechanizmów chroniących demaskatora.

Choć pierwszym adresatem rzeczonego postulatu jest społeczeństwo obywatelskie, to nie jest ono adresatem jedynym. Paralelnie do niego na znaczeniu zyskuja działania podejmowane przez odpowiedzialną firmę. Może ona pomnażać kapitał społecznego zaufania poprzez konsekwentnie prowadzoną politykę otwartości na głos oponentów posługujących się rzeczowymi argumentami. Jej szybka reakcja na zło, którego jest sprawczynią powoduje, że przedmiotem krytyki staje się bardziej to, co wzbudziło społeczny opór, niż sama organizacja. Jakkolwiek płynne jest owo rozróżnienie, nie do przecenienia w podobnych wypadkach jest jasno deklarowana przez złoczyńcę wola porozumienia się ze społeczeństwem. Odwracając tę zależność: ze społecznego punktu widzenia, warunkiem odpowiedzialnego gospodarowania, jest udział przedsiębiorstwa w publicznej debacie na temat sprawiedliwych i skutecznych zasad posługiwania się metodą demaskacji. Podkreślenia wymaga, iż

${ }^{20} \mathrm{P}$. Rotengruber, Interesariusz, demaskator... i ten trzeci. O zamieszaniu wokół kluczowych pojęć etyki gospodarczej, „Prakseologia” 2016, vol. 158, nr 1, s. 65-86.

${ }^{21}$ J. Habermas, op. cit., s. 50-51. 
w powszednich realiach zależność ta uchodzić może za detal niemający wpływu na wizerunek organizacji. Zyskuje natomiast na znaczeniu, kiedy wychodzą na jaw jej nadużycia. Podsumowując, pośród czynników składających się na społeczną odpowiedzialność przedsiębiorstwa na znaczeniu zyskują te umożliwiające mu godzenie celów partykularnych (powiernictwo) z uniwersalnymi (dobroczynność). Nie mniej ważnym aspektem tego przedsięwzięcia jest możliwość szacowania przez nie korzyści wynikających z wyboru CSR-owej strategii zarządczej.

Przeniesienie doktryny społecznie odpowiedzialnego kierowania na grunt pozagospodarczy wymaga uwzględnienia dwóch przesłanek. Po pierwsze, w grę wchodzą li tylko te instytucje, które - z uwagi na posiadane uprawnienia bądź charakter świadczonych usług - winne są społeczeństwu rzetelność i transparentność. W największym skrócie chodzi o organizacje realizujące zadania publiczne. Powołane do życia po to, by służyć wspólnocie politycznej tracą sens (a przynajmniej wiarygodność), kiedy przestają być społecznie odpowiedzialne. Po drugie, choć instytucje te finansowane są ze środków publicznych, sposób zarządzania nimi musi brać pod uwagę rygory ekonomiczne oraz ograniczenia prawne respektowane przez przedsiębiorstwo. Zgodnie z porównaniem dokonanym we wprowadzeniu, ustalić trzeba, kto jest odbiorcą finalnym produktu wytwarzanego przez organizacje pierwszego typu. Doprecyzowując myśl, kto korzysta z ich usług, opiniuje ich działalność oraz łoży na ich utrzymanie. Ponieważ w wymienione role wcielają się różni aktorzy, deklaracje odnośnie do odpowiedzialności instytucji publicznych stają się niejednoznaczne. Skoro powołano je do życia po to, by służyły obywatelom, utrzymywane są z budżetu państwa lub jednostek samorządu terytorialnego, kontrolowane natomiast przez organy władzy publicznej, to na usta ciśnie się pytanie: przed którym z wymienionych podmiotów ponoszą one największą odpowiedzialność?

Wyrażoną obawę mogą przesłonić treści składające się na (skutecznie realizowaną) strategię wizerunkową. Rozpraszają obawy, lecz nie rozwiązują problemu. W publicznym oglądzie oceniana instytucja zachowuje walor nieskazitelności. Postępowanie to jednak załatwia mniej niż może się zdawać jej liderom. Poza ich zasięgiem pozostają bowiem prywatne opinie oraz towarzyszące im emocje. Spostrzeżenie to - na powrót - wiedzie do postulatu społecznie odpowiedzialnego zarządzania. W proponowanej interpretacji tej doktryny do obowiązków menedżera należy rozeznawanie się $\mathrm{w}$ nastrojach interesariuszy oraz pozyskiwanie społecznego zaufania poprzez promocję etycznej demaskacji jako metody służącej ochronie dobra wspólnego. Instytucja publiczna dopiero wtedy uchodzić może za społecznie odpowiedzialną, gdy werdykt ów wydadzą ci, których on dotyczy ${ }^{22}$.

Tymczasem pod latarnią najciemniej. Badania nad tym, jak odróżnić kierowanie społecznie odpowiedzialne od jego pozorów są domeną uniwersytetu. Choć refleksję nad poruszoną kwestią zainicjowali praktycy gospodarczy, to jej rozwinięcie nie byłoby możliwe bez udziału naukowców oraz instytucji organizujących ich pracę. $Z$ tego względu uniwersytet uchodzić może za depozytariusza wiedzy o regułach zarządzania zgodnego z interesem społecznym. Uniwersytet pozyskuje tę wiedzę, rozwija ją, wykorzystuje do celów dydaktycznych, zamienia w narzędzie

${ }^{22} \mathrm{~K}$. Leja, Zarzadzanie uczelniq. Koncepcje $i$ wspótczesne wyzwania, Oficyna a Wolters Kluwer business, Warszawa 2013, s. 183-208. 
badawcze oraz metodę mediacji. Ujmując rzecz lapidarnie, uczy innych, jak być powinno. Niestety on sam niejednokrotnie nie przestrzega tego, czego sam naucza. Rozdarty pomiędzy oczekiwaniami różnych odbiorców finalnych otwiera listę organizacji posługujących się podwójną miarą. Sformułowany zarzut - także w tym przypadku - można odpierać za pomocą argumentów wizerunkowych ${ }^{23}$. Nie sposób natomiast stawić mu czoła, kiedy akcent położony zostaje na kryteriach społecznej odpowiedzialności instytucji publicznej. Na znaczeniu zyskuje wówczas wątpliwość odnośnie do znikomego dostrzegania przez uniwersytet jego społecznych interlokutorów. Trudno zakładać przecież, że instytucja ta nikomu nie zagraża oraz nie ma nic do ukrycia.

Uniwersytet zachowuje podziwu godną spolegliwość wobec politycznych decydentów ustanawiających - co raz to nowe - zasady jego funkcjonowania. Gwoli przypomnienia, bez większego oporu przeszły zmiany dotyczące finansowania szkolnictwa wyższego (wynikiem których jest m.in. odgórnie wyznaczany współczynnik scholaryzacji), trybu rekrutacji (w oparciu o nową maturę), systemu punktów ECTS itd. O ile życzenia politycznych odbiorców produktu akademickiego spełniane są bez szemrania, o tyle głos strony społecznej jest ledwie słyszalny. Zdawałoby się, że senat uczelni, rada wydziału czy rada instytutu to miejsca, w których przynajmniej interesariusze wewnętrzni (studenci, doktoranci, pracownicy) mogą przedstawić to, co budzi ich sprzeciw. Uprawnienie to jednak pomija nieprzezwyciężalną dla wielu - przeszkodę w postaci zależności kompetencyjnych. Jak mianowicie, w zgodzie z prawem i akademickim obyczajem, skutecznie kwestionować słuszność decyzji podjętych przez wymienione organy? Jak wpływać na autorytety stające na ich czele? Do kogo, na przykład, ma zwrócić się doktorant źle traktowany przez promotora albo studenci niesprawiedliwie ocenieni przez wykładowcę będącego równocześnie dziekanem, dyrektorem instytutu bądź kolegą dyrektora?

Do nie mniej pesymistycznych wniosków wiodą poszukiwania miejsca, w którym wybrzmiewałby głos interesariuszy zewnętrznych uniwersytetu oraz jego (potencjalnych) demaskatorów ${ }^{24}$. Ich głos nie wybrzmiewa wcale. Nie wybrzmiewa, gdyż próżno szukać w strukturze uniwersytetu mechanizmu służącego ich promocji i ochronie ${ }^{25}$. Ani troska o interesariuszy, ani ochrona demaskatorów nie są zadaniami spędzającymi sen z powiek władzom uczelni wyższych w Polsce. Odnosząc to spostrzeżenie do ustępstw, jakie poczyniły one na rzecz środowisk politycznych warto zapytać o straty ponoszone przez społeczeństwo. Zgodnie z przykładem

\footnotetext{
${ }^{23}$ Ze świecą szukać uczelni, która poruszonych kwestii nie uwzględnia w swojej strategii rozwoju.

${ }^{24}$ Cf. J. Wieczorek, Mobbing akademickich demaskatorów, Mobbing akademickich demaskatorów, artykuł zamieszczony w serwisie Mediator Akademicki Kontra Mobbing 2009, https://nfamob.wordpress.com/tag/demaskatorzy/ (data dostępu: 12.08.2016); W. Korczyński, Błędy demaskatorów, Niezależne Forum Akademickie, 2009, http://www.nfa.pl/print.php?what=article\&id=600 (data dostępu: 12.08.1016).

${ }^{25}$ A. Piotrowska-Piątek, Relacje szkół wyższych z interesariuszami zewnętrznymi. Konwent jako organizacja pomostowa, „Zeszyty Naukowe Politechniki Śląskie. Seria: Organizacja i zarządzanie” 2014, vol. 76, s. 167-178. Cf. A. Wojciechowska-Nowak, Jak zdemaskować szwindel? Czyli krótki przewodnik po whistle-blowingu, Fundacja im. S. Batorego, Warszawa 2008, http://www.batory.org.pl/doc/Poradnik_Jak_zdemaskowac_szwindel_grudzien_2008.pdf, s. 51-62 (data dostępu: 16.07.2016).
} 
podanym we wprowadzeniu, uprawnienia uniwersytetu do certyfikacji wiedzy i umiejętności w coraz mniejszym stopniu znajdują zastosowanie w procesie reprodukcji elit. Oba czynniki tworzą układ wysoce dysfunkcjonalny. Wymogi prawne dotyczące stopni i tytułów naukowych (bądź artystycznych) powodują, że studiowanie jest dla wielu warunkiem koniecznym rozwoju zawodowego. Czy jednak warunkiem wystarczającym? Tę - między innymi - kwestię powinni rozstrzygać społeczni partnerzy uniwersytetu ${ }^{26}$.

Postulat społecznej oceny (dominujących) instytucji wiedzy oraz towarzyszący temu wymóg orientowania się przez ich włodarzy w nastrojach społecznego otoczenia korespondują $\mathrm{z}$ - prowadzonymi przez polskie uczelnie - badaniami jakości kształcenia. Samokontrola wyprzedza w tym postępowaniu krytykę zewnętrzną. Wyprzeda a zarazem zastępuje. Nie chodzi przecież o to, by interesariusze zewnętrzni i demaskatorzy przejmowali inicjatywę w komentowaniu spraw uniwersytetu. Oznaczałoby to popadanie w drugą skrajność. Ich obawy, choćby najlepiej uzasadnione, nie dają miarodajnego wglądu w uniwersyteckie realia. Stąd wniosek, iż rozwiązaniem modelowym jest dialog uwzględniający możliwości tej instytucji oraz potrzeby i oczekiwania tych, do których zwraca się ona. Tymczasem jest, jak jest. Miejsce dialogu zajmuje monolog. Uderzająca w tym procesie jest obecność milczącej większości z rzadka zagrażającej integralności (zwłaszcza integralności wizerunkowej) tegoż autopoietycznego systemu ${ }^{27}$. Pojęciowe nawiązania do Niklasa Luhmanna i Ralfa Dahrendorfa są przy tym połowicznie użyteczne. Instytucja ta bowiem nie musi obawiać się o swoją przyszłość. Bez względu na to, jak bardzo zdystansuje się do społecznych partnerów, wciąż będzie im bowiem potrzebna jako dystrybutor uprawnień.

Z dokonanego przybliżenia wynika, że bronią uniwersytetu (możliwą do wykorzystania) w walce $\mathrm{z}$ tymi, którzy chcieliby go krytykować jest przemoc. W przypadku interesariuszy wewnętrznych dysponuje on paletą środków wynikających ze stosunku pracy oraz akademickiego obyczaju. Reszta oponentów pada ofiarą bardziej wyrafinowanych technik deprecjonowania. Pierre Bourdieu piesze o przemocy symbolicznej polegającej na utrwalaniu się przekonania o (kompetencyjnym) prymacie jednych nad innymi ${ }^{28}$. W realiach akademickich przejawia się ona monopolizacją uprawnień przez środowiska naukowe do komentowania spraw własnych i cudzych. Michel Foucault kładzie nacisk na symboliczną dominację utrzymywaną przez posiadacza wiedzy o pożądanych formach ładu zbiorowego ${ }^{29}$. Wreszcie Stephen Lukes wyjaśnia jak - w praktyce politycznej wspólnot Zachodu - elity władzy osiągają przewagę (perswazyjną) nad ich społecznym powiernikiem $^{30}$.

\footnotetext{
${ }^{26}$ Cf. M. Geryk, Spoleczna odpowiedzialność uczelni w percepcji jej interesariuszy. Raport z badań, Oficyna Wydawnicza SGH, Warszawa 2010.

${ }^{27}$ N. Luhmann, Teoria polityczna państwa bezpieczeństwa socjalnego, przeł. G. Skąpska, PWN, Warszawa, 1994; R. Dahrendorf, Nowoczesny konflikt spoteczny. Esej o polityce wolności, przeł. W. Niepokólczycki i inni, Czytelnik, Warszawa 1993.

${ }^{28}$ P. Bourdieu, Zaproszenie do socjologii refleksyjnej, przeł. A. Sawisz, Oficyna Wydawnicza, Warszawa 2001, s. 162-163.

${ }^{29}$ M. Foucault, Trzeba bronić spoteczeństwa, przeł. M. Kowalska, Wyd. KR, Warszawa 1998, s. 47-48, 86.

${ }^{30}$ S. Lukes, Power: A Radical View, Macmillan, London 1981.
} 
Ponieważ ostatnia propozycja najpełniej oddaje złożoność procesu (symbolicznego) ubezwłasnowolnienia politycznego interlokutora, warto dokonać jej przybliżenia. Lukes włącza się spór o warunki demokratycznej kontroli grup przywódczych. Poglądom pluralistów - zwolenników opcji jednowymiarowej, oraz elitarystów - zwolenników opcji dwuwymiarowej, przeciwstawia on własne trójwymiarowe ujęcie ${ }^{31}$. Opcja jednowymiarowa skojarzona zostaje przez Lukesa z przesłaniem autorów głoszących, iż skala napięć wytwarzanych przez politycznie i gospodarczo dominujących aktorów, pozostaje w ścisłej odpowiedniości z zakresem swobód spontanicznie dogadującego się społeczeństwa. Zdaniem Roberta A. Dahla oraz Nelsona W. Polsby’ego władza jest tym bliższa ideałowi społeczeństwa obywatelskiego, im gwałtowniejszy i autentyczniejszy jest konflikt dzielący dominujące ugrupowania polityczne ${ }^{32}$. Wśród zwolenników opcji dwuwymiarowej Lukes wymienia Floyda Huntera i Charlesa Millsa. Posiłkują się oni obserwacją, iż dystrybucja władzy w Stanach Zjednoczonych w II połowie XX wieku, jest domeną „społecznie nieodpowiedzialnych elit”. Dwuwymiarowość ich przywództwa polega na tym, że ich celem jawnym jest potęgowanie politycznych różnic, celem ukrytym natomiast ich niwelowanie. Elity władzy, choć na zewnątrz podzielone, tworzą homogeniczną grupę nacisku zdolną do

(...) wykluczania interesów poszczególnych jednostek czy grup podczas debat prowadzonych na zgromadzeniach legislacyjnych, w izbach rad $i$ innych miejscach, gdzie podejmuje się decyzje wpływające na życie wspólnoty ${ }^{33}$.

Lukes tyleż podziela poglądy elitarystów, co uważa je za nie dość radykalne. Krytykę ukrytego wymiaru władzy uzupełnia on rozważaniami nad niezależnym od woli i wiedzy społecznego aktora systemem znaków i symboli porządkujących sferę publiczną ${ }^{34}$. Wynikiem zaproponowanej korekty jest ujawnienie problemów nierozpoznanych (bądź nie w pełni rozpoznanych) przez zwolenników opcji dwuwymiarowej. Oprócz działań zakulisowych, elity władzy mogą bezkarnie nadużywać swoich uprawnień, gdyż potrafią manipulować kryteriami ich oceny (trzeci wymiar władzy). Wywierają one presję na warstwy pozbawione dystansu do społecznych faktów, wykorzystują luki w systemie kierowania i kontroli. To, co miało chronić społeczeństwo przez przemocą środowisk politycznych, czynić je zdolnym do wyrażania własnej opinii, zamienia się w narzędzie panowania nad nim.

Potrzebę przeniesienia politologicznych rozważań w przestrzeń uniwersytetu - gwoli przypomnienia - uzasadnia pytanie o miejsce, w którym jego krytycy mogliby (z powodzeniem) inicjować debatę na temat mankamentów tej instytucji oraz ich społecznych skutków. Zgodnie z rozpoznaniem przedstawicieli teorii racjonalnego wyboru, jedni nie widzą szwankujących mechanizmów dystrybucji wiedzy i umiejętności; inni widzą je, lecz - z najrozmaitszych względów - umywają ręce;

\footnotetext{
${ }^{31}$ Ibidem, s. 9-23.

${ }^{32}$ R.A. Dahl, Demokracja i jej krytycy, przeł. S. Amsterdamski, Znak, Kraków 1995, s. 170-188.

${ }^{33}$ B. Hindess, Filozofie władzy. Od Hobbesa do Foucaulta, przeł. D. Leszczyński, L. Rasiński, PWN, Warszawa-Wrocław 1999, s. 30.

${ }^{34}$ S. Lukes, op. cit., s. 19-30.
} 
jeszcze inni protestują, lecz są ignorowani przez tych, których protest dotyczy ${ }^{35}$. Argumentem w tym wnioskowaniu jest brak przesłanek potwierdzających tezę przeciwną. Pomimo ogromu wyzwań, przed jakimi stają polskie uczelnie, ze świecą szukać przykładów ich autentycznego angażowania się w dialog ze społeczeństwem $^{36}$. Podkreślenia wymaga, iż nie chodzi tu o „dialog” podejmowany według kryteriów ustalanych przez uniwersytet. Celem postulowanego przedsięwzięcia jest ochrona jego społecznych partnerów. Dopóki nie staną się oni zdolni do upominania się o to, co leży w interesie każdego nich z osobna, oraz o to, co - ich zdaniem zagraża interesowi publicznemu, dopóty (polski) uniwersytet, oprócz grzechu zaniechania, obciążał będzie się winą za niestosowanie się do tego, czego uczy. To o jeden zarzut więcej.

\section{Homo Academicus Polonus. Tytułem zakończenia}

W czasach postępującej atrofii więzi społecznej - kryzysu państwa opiekuńczego, wzmożonej konkurencji na rynku pracy, czy, wybuchających w coraz to nowych miejscach, wojen kulturowych - postulat społecznej odpowiedzialności instytucji publicznych zyskuje na znaczeniu. Mimowolnie poszukujemy przewodników, którzy umieliby odwrócić niekorzystny trend. Poczesne miejsce pośród nich zajmuje uniwersytet. Nawet jeśli przyjąć, iż nie ma on monopolu na wiedzę o tym, jak kierować wspólnymi sprawami, trudno kwestionować, że skupia on w swoim ręku uprawnienia do jej certyfikacji obejmujące prestiż osoby certyfikowanej. Oczywistość tego stwierdzenia bierze się stąd, że zarówno instytucje publiczne, jak organizacje komercyjne - niemal bez wyjątku - zarządzane są przez osoby będące absolwentami uczelni wyższych.

Uniwersytet wiedzie prym w badaniach dotyczących m.in. zasad zarządzania społecznie odpowiedzialnego. Wiedzę tę zamienia w ofertę naukową i edukacyjną. Zdawałoby się, że to czyni uniwersytet arbitrem w sporach społecznych i politycznych. Tymczasem nic bardziej błędnego. Naukowe i edukacyjne zasoby uniwersytetu są towarem, którego odbiorcą finalnym jest polityczny zleceniodawca. Nie jest to, co prawda, odbiorca jedyny. To on płaci jednak za akademicki produkt, to on ustanawia ograniczenia odnośnie do trybu, w jakim produkt ów trafia w ręce jego społecznego odbiorcy. Konsekwencją rozdwojenia perspektyw ewaluacyjnych jest etyczna ambiwalencja uniwersytetu. Ponieważ powinien się on liczyć z głosem interesariuszy i demaskatorów, (niemal) konieczne w jego przypadku jest wytwarzanie pozorów społecznej odpowiedzialności.

\footnotetext{
${ }^{35}$ Por. J. Stiglitz, Globalizacja, przeł. H. Simbierowicz, PWN, Warszawa 2004, s. 7-12, 60, 78; K. Arrow, Eseje z teorii ryzyka, przeł. B. Samojlik, PWN, Warszawa 1979; idem, Granice organizacji, przeł. A. Erlich, PWN, Warszawa 1985, s. 25-52.

${ }^{36} \mathrm{~W}$ innym miejscu wyjaśniam, co postulat dialogu ma wspólnego z doktryną społecznej odpowiedzialności biznesu. P. Rotengruber, Dialogowe podstawy etyki gospodarczej, Wyd. Nauk. UAM, Poznań 2011, s. 166-250.
} 
Opisany stan rzeczy skłania do namysłu nad przyczynami, dla których środowiska akademickie tak łatwo poddają się presji okoliczności ${ }^{37}$. Zamiast pomnażać kapitał emancypacyjny oraz zamieniać go w narzędzie oporu przeciwko (nieodpowiedzialnym lub niekompetentnym) decydentom, środowiska te wybierają - zaczerpnięte ze świata polityki - metody „ogrywania” społecznego interlokutora polegające na zawłaszczaniu kryteriów ich komunikacyjnej poprawności. Skąd bierze się ich przyzwolenie na etyczną bylejakość. Jak radzą sobie one z dysonansem zachodzącym pomiędzy tym, czego uczą, a tym, co robią? Problemy te zasługują na wnikliwe zbadanie. Stąd, domykający niniejsze rozważania, postulat badań nad regułami życia akademickiego w Polsce ${ }^{38}$. Warto to uczynić nie tylko ze względu na naukowców. Następstwem uniwersyteckich zaniechań jest utrwalanie się wzorców postępowania ułatwiających innym instytucjom i grupom zawodowym wymykanie się spod społecznej kontroli ${ }^{39}$. Wiedza tych ostatnich - obejmująca ich uniwersyteckie doświadczenia - najwyraźniej nie idzie w las. Dlatego rzeczony postulat potraktować należy nie tylko jako zachętę do rachunku sumienia środowisk akademickich, lecz przede wszystkim, jako apel o podjęcie wspólnych poszukiwań kryterium społecznej wiarygodności uniwersytetu.

\section{Bibliografia}

Arrow K., Eseje z teorii ryzyka, przeł. B. Samojlik, PWN, Warszawa 1979.

Arrow K., Granice organizacji, przeł. A. Erlich, PWN, Warszawa 1985.

Ayer A.J., Language, Truth and Logic, Penguin, London 2001.

Beck U., Społeczeństwo ryzyka. W drodze do innej nowoczesności, przeł. S. Cieśla, Wyd. Nauk. SCHOLAR, Warszawa 2002.

Bourdieu P., Homo Academicus, Polity Press, Cambridge 1988.

Bourdieu P., Zaproszenie do socjologii refleksyjnej, przeł. A. Sawisz, Oficyna Wydawnicza, Warszawa 2001.

Dahl R.A., Demokracja i jej krytycy, przeł. S. Amsterdamski, Znak, Kraków 1995.

Dahrendorf R., Nowoczesny konflikt społeczny. Esej o polityce wolności, przeł. W. Niepokólczycki i inni, Czytelnik, Warszawa 1993.

Evan W.M., R.E. Freeman, Spótka i osoby żywotnie zainteresowane. Kapitalizm kantowski, przeł. E. Dratwa [w:] Etyka biznesu, red. L.V. Ryan, J. Sójka, Wyd. „W drodze”, Poznań 1997, s. 185-205.

Foucault M., Trzeba bronić społeczeństwa, przeł. M. Kowalska, Wyd. KR, Warszawa 1998.

\footnotetext{
${ }^{37}$ Cf. Z. Melosik, Uniwersytet $i$ spoleczeństwo. Dyskursy wolności wiedzy $i$ wladzy, Oficyna Wydawnicza „Impuls”, Kraków 2009.

${ }^{38}$ Badań inspirowanych dokonaniami Pierre`a Bourdieu. Cf. P. Bourdieu, Homo Academicus, Polity Press, Cambridge 1988.

${ }^{39}$ P. Rotengruber, Kodeks etyczny samorzadu zawodowego. Gwarancja bezpieczeństwa czy pułapka tatwowierności?, „Annales. Ethics in Economic Life” 2015, vol. 18, nr 1, s. 68-77.
} 
Freeman R.E., J. McVea, A Stakeholder Approach to Strategic Management, „Social Science Research Network Electronic Paper Collection” 2001, doi: 10.2139/ssrn.263511.

Freeman R.E., Strategic Management: A Stakeholder Approach, Pitman Publishing, Boston 1984.

Geryk M., Spoleczna odpowiedzialność uczelni w percepcji jej interesariuszy. Raport z badań, Oficyna Wydawnicza SGH, Warszawa 2010.

Geryk M., Społeczna odpowiedzialność uczelni, Oficyna Wydawnicza SGH, Warszawa 2012.

Habermas J., Faktyczność i obowiazywanie, przeł. A. Romaniuk, R. Marszałek, PWN, Warszawa 2005.

Hindess B., Filozofie władzy. Od Hobbesa do Foucaulta, przeł. D. Leszczyński, L. Rasiński, PWN, Warszawa-Wrocław 1999.

Hume D., Badania dotyczace zasad moralności, przeł. M. Filipczuk, T. Tesznar, Wyd. Zielona Sowa, Kraków 2005.

Inglehart R., Culture Shift in Advanced Industrial Societies, Princeton University Press 1990.

Korczyński W., Btędy demaskatorów, Niezależne Forum Akademickie, 2009, http://www. nfa.pl/print.php?what=article\&id=600.

Lakatos I., Społeczna odpowiedzialność nauki [w:] idem, Pisma z filozofii nauk empirycznych, przeł. W. Sady, WN PWN, Warszawa 1995, s. 363-366.

Leja K., Zarządzanie uczelniq. Koncepcje i współczesne wyzwania, Oficyna a Wolters Kluwer business, Warszawa 2013.

Lewicka-Strzałecka A., Odpowiedzialność moralna w życiu gospodarczym, IFiS PAN, Warszawa 2006.

Luhmann N., Teoria polityczna państwa bezpieczeństwa socjalnego, przeł. G. Skąpska, PWN, Warszawa 1994.

Lukes S., Power: A Radical View, Macmillan, London 1981.

Maslow A.H., Motywacja i osobowość, przeł. P. Sawicka, PAX, Warszawa 1990.

Melosik Z., Uniwersytet i społeczeństwo. Dyskursy wolności wiedzy i władzy, Oficyna Wydawnicza „Impuls”, Kraków 2009.

Mendel T., Partycypacja w zarządzaniu wspótczesnymi organizacjami, Wyd. Akademii Ekonomicznej w Poznaniu, Poznań 2001.

Mitchell R.K., B.R. Agle, D.J. Wood, Toward a Theory of Stakeholder. Identification and Salience: Defining the Principle of Who and What Really Counts, „Academy of Management Review" 1997, vol. 22, nr 4, s. 853-886.

Phillips R., R.E. Freeman, A.C. Wicks, What Stakeholder Theory Is Not, „Business Ethics Quarterly" 2005, vol. 13, nr 4, s. 479-502.

Piotrowska-Piątek A., Relacje szkół wyższych z interesariuszami zewnętrznymi. Konwent jako organizacja pomostowa, „Zeszyty Naukowe Politechniki Śląskie. Seria: Organizacja i zarządzanie" 2014, vol. 76, s. 167-178.

Rotengruber P., Dialogowe podstawy etyki gospodarczej, Wyd. Nauk. UAM, Poznań 2011.

Rotengruber P., Ideologia, anarchia, etyka. Dyskurs ponowoczesny a dialog, Wyd. Nauk. HUMANIORA, Poznań 2000.

Rotengruber P., Interesariusz, demaskator ... i ten trzeci. O zamieszaniu wokół kluczowych pojęć etyki gospodarczej, „Prakseologia” 2016, vol. 158, nr 1, s. 65-86. 
Rotengruber P., Kodeks etyczny samorzadu zawodowego. Gwarancja bezpieczeństwa czy putapka łatwowierności?, „Annales. Etyka w Życiu Gospodarczym”2014, vol. 18, nr 1, s. 37-48.

Rotengruber P., Moralność krańcowa jako przedmiot badania oraz jako wiedza o sposobach osiagania przewagi konkurencyjnej, „Annales. Etyka w Życiu Gospodarczym” 2013, vol. 16, s. $45-54$.

Sójka J., L.V. Ryan, Etyka biznesu, Wyd. „W drodze”, Poznań 1997.

Sójka J., Wstęp [w:] Etyka biznesu 'po Enronie', red. J. Sójka, Wyd. Fundacji Humaniora, Poznań 2005.

Stiglitz J., Globalizacja, przeł. H. Simbierowicz, PWN, Warszawa 2004.

Wicks C., R.E. Freeman, Organization Studies and the New Pragmatism: Positivism, Antipositivism, and the Search for Ethics, „Organization Science” 1998, vol. 9, nr 2, s. $123-140$.

Wieczorek J., Mobbing akademickich demaskatorów, artykuł zamieszczony w serwisie Mediator Akademicki Kontra Mobbing 2009, https://nfamob.wordpress.com/tag/demaskatorzy/.

Wojciechowska-Nowak A., Jak zdemaskować szwindel? Czyli krótki przewodnik po whistleblowingu, Fundacja im. S. Batorego, Warszawa 2008, http://www.batory.org.pl/doc/ Poradnik_Jak_zdemaskowac_szwindel_grudzien_2008.pdf.

Young S., Etyczny kapitalizm. Jak na powrót połaczyć prywatny interes z dobrem publicznym, przeł. W. Kisiel, METAmorfoza, Wrocław 2005. 